\title{
Appropriate and inappropriate neuroendocrine products in pulmonary tumourlets
}

\author{
John Gosney, A R T Green, W Taylor
}

\begin{abstract}
Pulmonary tumourlets are focal aggregates of neuroendocrine cells that occur in the periphery of the lung and may be associated with chronic inflammation and scarring. Six such lesions were seen in five lungs from a series of $\mathbf{3 5}$ pairs of lungs studied at necropsy. All were immunoreactive for neuronespecific enolase, protein gene product $9 \cdot 5$, and a range of neuroendocrine products. Of the peptides found in neuroendocrine cells in normal human lungs, gastrin releasing peptide was present in all tumourlets and calcitonin in all but one; none contained leucineenkephalin. Of a series of peptide and protein hormones not present in the neuroendocrine cells of healthy human lungs, growth hormone was present in all six tumourlets and adrenocorticotrophin in two. Identical patterns of peptide expression were displayed by neuroendocrine cells in the airway associated with the tumourlets in two cases. Such cells were increased in number and abnormally clustered. Aberrant expression of peptides might accompany the morphological changes in the pulmonary neuroendocrine cells seen in diseased lungs, their florid focal proliferation occasionally resulting in the formation of a tumourlet.
\end{abstract}

Pulmonary tumourlets are small aggregates of nests of neuroendocrine cells in a fibrous stroma, usually found incidentally in the periphery of a lung in close proximity to a terminal bronchiole and sometimes in association with bronchiectasis, chronic suppuration, and scarring. ${ }^{1-3}$ Several investigators have noted their tendency to arise when there are increased numbers of pulmonary neuroendocrine cells, often in the form of nodular intraepithelial clusters, in surrounding airways ${ }^{2-5}$ a process in which the increase in number and disturbance of the normal morphology and distribution of these cells is accompanied by the presence within them of substances not normally found there. ${ }^{4-5}$ The aim of this study was to investigate the prevalence of certain neuroendocrine products, both "appropriate" and "inappropriate" to pulmonary neuroendocrine cells, in a series of tumourlets and to relate these findings to changes in the neuroendocrine cells in adjacent airways.

\section{Methods}

Tumourlets were sought in the lungs of 35 patients coming to necropsy, the only criterion for selection being that the necropsy was performed within 48 hours of death. In each case the left lung was distended with Bouin's solution, allowed to fix for 48 hours, and cut into $1 \mathrm{~cm}$ sagittal slices. At least 12 random blocks were then taken from each, a numbered perspex grid being placed over each slice, and a table of random numbers being used to select the blocks, with the proviso that large airways and vessels were avoided. Multiple blocks were taken from the non-distended right lungs at the time of the necropsy and these were also fixed in Bouin's solution for $\mathbf{4 8}$ hours. After being embedded in paraffin wax sections were stained with haematoxylin and eosin and the elastic van Gieson method and examined by light microscopy.

When a tumourlet was discovered, serial sections of the block in which it was contained were cut and immunochemically labelled for neurone specific enolase and protein gene product 9.5 , markers of pulmonary neuroendocrine cells, ${ }^{67}$ and a series of products of neuroendocrine cells (table 1 ) by the peroxidase-antiperoxidase technique. ${ }^{8} \quad$ These $^{2}$ substances were chosen for study because either they are found in the neuroendocrine cells of the normal human lung (gastrin releasing peptide, calcitonin, leucineenkephalin, and 5-hydroxytryptamine) $)^{910}$ or they have been reported in these cells in diseased lungs or in bronchial neoplasms (adrenocorticotrophin, somatostatin, vasoactive intestinal polypeptide, arginine-vasopressin, growth hormone, and calcitonin gene related peptide). ${ }^{4511}$ The source, working dilution, and nature of the control tissues are shown for each of the primary antisera in table 1 , as are the details of the corresponding antigens used in the absorption studies. The primary antiserum was incubated with tissue sections for one hour and then linked to rabbit peroxidase-antiperoxidase complex $(1: 100)$ by swine anti-rabbit serum (1:50). Aminoethylcarbazole was the chromogen.

All the usual positive and negative tissue controls were used, including immunolabelling with aliquots of antiserum preabsorbed by overnight incubation at $4^{\circ} \mathrm{C}$ with a range of concentrations of its homologous antigen (table 1). In all cases immunolabelling was quenched by addition of $5-15 \mathrm{nmol} / \mathrm{ml}$ of antigen.

The presence or absence in each tumourlet 
Table 1 Details of antisera and antigens

\begin{tabular}{|c|c|c|c|}
\hline Neuroendocrine product & $\begin{array}{l}\text { Source and working } \\
\text { dilution of antiserum }\end{array}$ & Control tissue & $\begin{array}{l}\text { Nature, source, and purity } \\
\text { of antigen for preabsorption }\end{array}$ \\
\hline Neurone specific enolase (NSE) & Dako Corporation; 1:500 & Human pancreas & Not done \\
\hline Protein gene product (PGP) 9.5 & Ultraclone; 1:100 & Human pancreas & Not done \\
\hline Gastrin releasing peptide (GRP) & $\begin{array}{l}\text { Immunonuclear Corporation; } \\
1: 500\end{array}$ & Human fetal lung & Porcine GRP (CRB), > 95\% \\
\hline Calcitonin (CT) & Ortho Diagnostics; 1:500 & $\begin{array}{l}\text { Medullary carcinoma of thyroid } \\
\text { gland }\end{array}$ & Human calcitonin $(\mathrm{CRB}),>95 \%$ \\
\hline Leucine-enkephalin (LEU) & Peninsula Laboratories; 1:400 & Human adrenal medulla & Leucine-enkephalin (CRB), 87\% \\
\hline 5-Hydroxytryptamine (5-HT) & Miles Scientific; 1:300 & Human ileum & Not done \\
\hline Adrenocorticotrophin (ACTH) & Ortho Diagnostics; 1:500 & Human adenohypophysis & Human ACTH (1-39) (CRB), > 95\% \\
\hline Somatostatin (ST) & Ortho Diagnostics; 1:500 & Human pancreas & Somatostatin-28 (CRB), > 95\% \\
\hline Arginine-vasopressin (AVP) & ICN Immunobiologicals; $1: 2500$ & Human neurohypophysis & Arginine-vasopressin (CRB), $>95 \%$ \\
\hline $\begin{array}{l}\text { Vasoactive intestinal polypeptide } \\
\text { (VIP) }\end{array}$ & Incstar; $1: 800$ & Human colon & Human/porcine/rat VIP (CRB), $77^{\%} \%$ \\
\hline $\begin{array}{l}\text { Calcitonin gene related peptide } \\
\text { (CGRP) }\end{array}$ & Milab; $1: 4800$ & Medullary carcinoma of thyroid & $\begin{array}{l}\text { Calcitonin gene related peptide } \\
(\text { CRB }),>95 \%\end{array}$ \\
\hline Growth hormone (GH) & Ortho Diagnostics; 1:500 & Human adenohypophysis & $\begin{array}{l}\text { Natural human growth hormone } \\
\text { (Peninsula Laboratories), } 85 \%\end{array}$ \\
\hline
\end{tabular}

of neurone specific enolase, protein gene product $9 \cdot 5$, and the cell products sought was recorded and their distribution was defined according to whether they were present in all, most, or few of the component cells. The morphology, distribution, and content of neuroendocrine cells in the airways adjacent to the tumourlet were also noted.

\section{Results}

Six tumourlets were identified in five lungs from the 35 pairs of lungs. The morphology of the tumourlets, the pathological changes in the lungs containing them, and the age, sex, and cause of death of each of the five subjects in whom they were found are shown in table 2 , which also shows the extent and pattern of immunoreactivity for neuroendocrine products in the tumourlets.

The five subjects ranged in age from 62 to 78 (mean 72) years; four were female. One lung contained abscesses and focal scarring, but neither suppuration nor fibrosis was a conspicuous feature in the others (table 2).

Morphologically, all six tumourlets were typical, ${ }^{1}$ consisting of tiny aggregates of nests of uniform cells with spherical or ovoid nuclei and scant cytoplasm in a connective tissue stroma of variable density (fig 1). The largest was about 3 $\mathrm{mm}$ in diameter. All but one were clearly associated with a terminal bronchiole.

All six tumourlets showed strong, confluent labelling for neurone specific enolase and

Table 2 Details of subjects, pulmonary pathological changes, and morphology and content of tumourlets

\begin{tabular}{|c|c|c|c|c|c|c|c|c|c|c|c|c|c|}
\hline \multirow{2}{*}{$\begin{array}{l}\text { Age } \\
(y), \\
\text { sex }\end{array}$} & \multirow{2}{*}{$\begin{array}{l}\text { Pathological changes in } \\
\text { surrounding lung and } \\
\text { cause of death }\end{array}$} & \multirow[b]{2}{*}{$\begin{array}{l}\text { Morphology of } \\
\text { tumourlet }\end{array}$} & \multicolumn{11}{|c|}{ Content of tumourlet ${ }^{\star}$} \\
\hline & & & $\begin{array}{l}N S E \mid \\
P G P\end{array}$ & $G R P$ & $C T$ & $L E U$ & $5-H T$ & $A C T H$ & $S T$ & $A V P$ & $V I P$ & $C G R P$ & $G H$ \\
\hline $77, \mathrm{~F}$ & $\begin{array}{l}\text { Bronchopneumonia with } \\
\text { abscess formation, focal } \\
\text { scarring: SEPTICAEMIA } \\
\text { DUE TO PYOGENIC } \\
\text { ARTHRITIS }\end{array}$ & $\begin{array}{l}\text { Aggregates of spheroidal } \\
\text { cells in delicate } \\
\text { fibrous stroma }\end{array}$ & ++ & ++ & + & 0 & 0 & 0 & 0 & 0 & 0 & 0 & ++ \\
\hline $62, \mathrm{~F}$ & $\begin{array}{l}\text { Centrilobular emphysema, } \\
\text { bronchopneumonia, } \\
\text { single infarct: } \\
\text { MYOCARDIAL INFARCTION } \\
\text { DUE TO CORONARY } \\
\text { THROMBOSIS }\end{array}$ & $\begin{array}{l}\text { Separate aggregates of } \\
\text { spheroidal or fusiform } \\
\text { cells in fibrous stroma } \\
\text { of varying density }\end{array}$ & ++ & ++ & ++ & 0 & + & 0 & 0 & 0 & 0 & 0 & + \\
\hline $78, \mathrm{~F}$ & $\begin{array}{l}\text { Anthracosis, early } \\
\text { centrilobular } \\
\text { emphysema: INTESTINAL } \\
\text { INFARCTION DUE TO } \\
\text { MESENTERIC THROMBOSIS }\end{array}$ & $\begin{array}{l}\text { Aggregates of spheroidal } \\
\text { cells in scanty stroma }\end{array}$ & ++ & + & ++ & 0 & 0 & + & 0 & 0 & 0 & 0 & + \\
\hline $68, M$ & $\begin{array}{l}\text { Squamous metaplasia of } \\
\text { airways, multiple small } \\
\text { thromboemboli: } \\
\text { HAEMATEMESIS DUE To } \\
\text { GASTRIC ULCERATION }\end{array}$ & $\begin{array}{l}\text { Aggregates of spheroidal } \\
\text { cells in dense fibrous } \\
\text { stroma }\end{array}$ & ++ & ++ & + & 0 & + & + & 0 & 0 & 0 & 0 & ++ \\
\hline \multirow[t]{2}{*}{$77, \mathrm{~F}$} & \multirow[t]{2}{*}{$\begin{array}{l}\text { Foci of intra-alveolar } \\
\text { haemorrhage: } \\
\text { CARCINOMATOSIS, } \\
\text { PRIMARY SITE UNKNOWN }\end{array}$} & $\begin{array}{l}\text { Perivascular aggregates } \\
\text { of spheroidal cells } \\
\text { with extension into } \\
\text { pulmonary vein }\end{array}$ & ++ & ++ & ++ & 0 & 0 & 0 & 0 & 0 & 0 & 0 & ++ \\
\hline & & $\begin{array}{l}\text { Subpleural aggregates of } \\
\text { spheroidal cells with } \\
\text { minimal stroma }\end{array}$ & ++ & ++ & 0 & 0 & 0 & 0 & 0 & 0 & 0 & 0 & + \\
\hline
\end{tabular}

$\star++$ indicates labelling of all or most cells, + indicates labelling of occasional cells, 0 indicates no labelling.

For abbreviations see table 1 . 
Figure 1 Typical tumourlet from the lung of a 68 year old man. It is uniformly positive for protein gene product 9.5 and arises in association with a terminal bronchiole (arrowhead).

(Peroxidase-

antiperoxidase.)

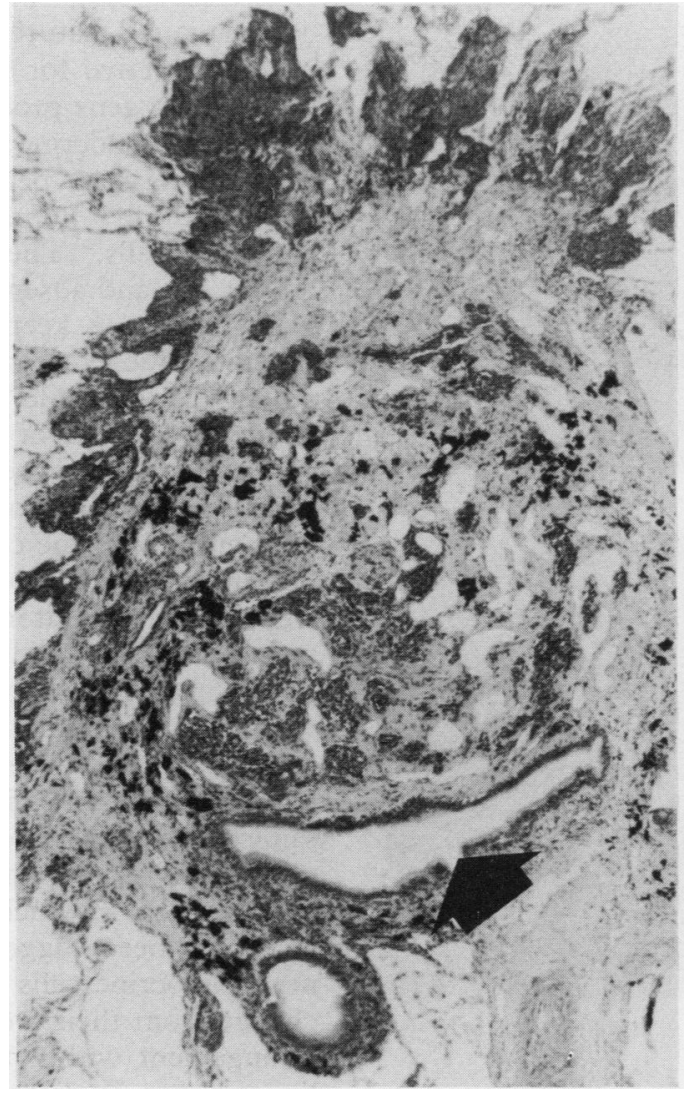

protein gene product 9.5 and all but one for gastrin releasing peptide, the mammalian analogue of bombesin (fig 2), the remaining lesion showing a more focal pattern of immunoreactivity for this peptide. Labelling for calcitonin was variable in strength and extent and absent from one tumourlet. Two of the six showed immunoreactivity for 5hydroxytryptamine, which was focal in both. None showed labelling for leucine-enkephalin.

Of those peptides not found in the neuroendocrine cells of healthy lungs but sometimes seen in diseased lungs or bronchial neoplasms, neither somatostatin, arginine-vasopressin, vasoactive intestinal polypeptide, nor calcitonin gene related peptide could be detected by labelling. Strong immunoreactivity for adrenocorticotrophin was seen focally in two of the tumourlets (fig 3), and all six showed immunoreactivity for growth hormone, which was widespread in three and focal in the remainder (fig 4).

Only in the airway immediately adjacent to the tumourlets was any disturbance of the normal morphology, pattern of distribution, or content of neuroendocrine cells obvious. This was particularly noticeable in two instances, where the regular, evenly spaced arrangement of these cells evident in airways in the same block of tissue just a short distance from the tumourlet was replaced by rows of abnormally clustered cells displaying the same pattern of peptides as the associated tumourlets (fig 5). Elsewhere the small number of neuroendocrine cells, as shown by immunoreactivity for neurone specific enolase and protein gene product $9 \cdot 5$, contained predominantly gastrin

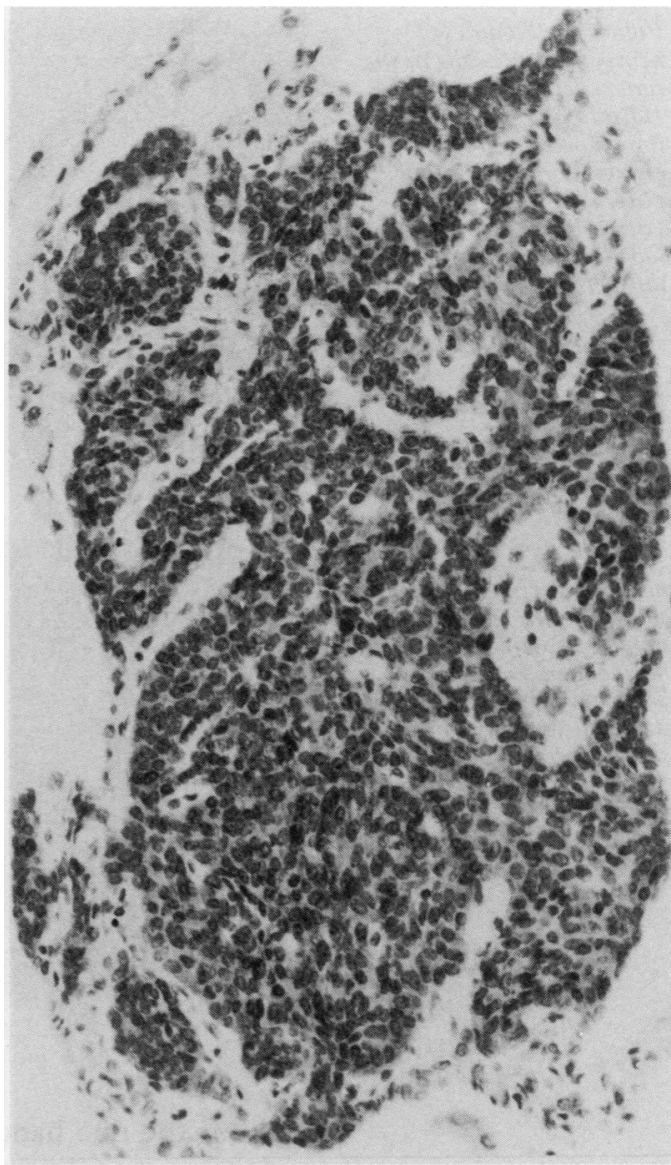

Figure 2 Uniform labelling of a tumourlet for gastrin releasing peptide. All but one tumourlet showed confluent labelling for this peptide. (Peroxidase-antiperoxidase.)

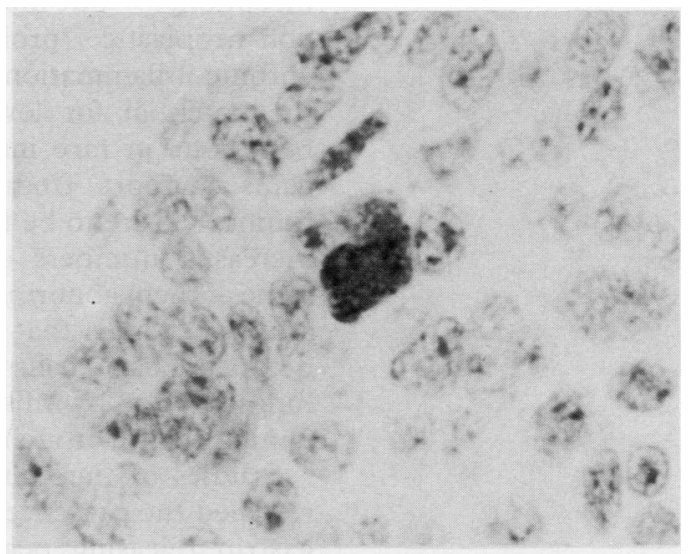

Figure 3 A single cell, strongly immunoreactive for adrenocorticotrophin, in the tumourlet shown in figure 1. Two of the six tumourlets in this series showed focal immunoreactivity for this peptide. (Peroxidaseantiperoxidase.)

releasing peptide with a lesser frequency of calcitonin, displaying none of the peptides not normally associated with pulmonary neuroendocrine cells.

\section{Discussion}

Since the earliest description by Pagel in $1926^{12}$ of the tiny proliferations of pulmonary neuroendocrine cells, ${ }^{2313}$ which Whitwell later termed tumourlets, ${ }^{1}$ their precise nature and relation to normal pulmonary neuroendocrine 
Figure 4 Nodules of neuroendocrine cells in the tumourlet shown in figure 1 displaying immunoreactivity for growth hormone. Some parts of the lesion (arrowhead) were not labelled. (Peroxidaseantiperoxidase.)

Figure 5 Cluster of neuroendocrine cells and a solitary cell immunoreactive for growth hormone in a respiratory bronchiole immediately adjacent to the tumourlet shown in figure 2 (Peroxidase-antiperoxidase.)
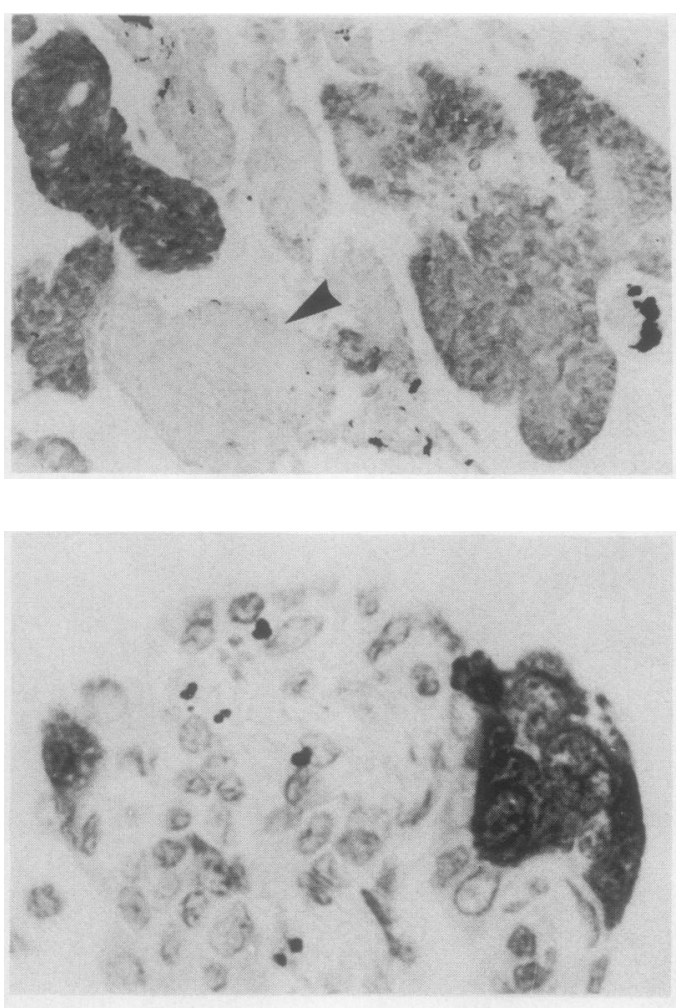

cells on the one hand and pulmonary neuroendocrine neoplasms ("carcinoid" tumours and small cell carcinomas) on the other has been debated. ${ }^{1-313-21}$ Some, particularly early authors, regarded them as neoplastic from their inception, ${ }^{14-16}$ but most consider them to be a non-neoplastic proliferative response to chronic inflammation and fibrosis, albeit with the potential for low grade local malignant behaviour in rare instances. $.^{1-3} 17-20$ This view gains support from studies showing that tumourlets are to be found in a background of increased numbers of neuroendocrine cells, some of them abnormally clustered, in adjacent airways $^{2-5}$ and that increased numbers of neuroendocrine cells appear in the airways of lungs affected by inflammatory disease or containing ectatic bronchi. ${ }^{422}$

Studies of the content of tumourlets have revealed the presence within them not only of gastrin releasing peptide, calcitonin, and 5hydroxytryptamine, ${ }^{2324}$ substances present in the neuroendocrine cells of healthy lungs, ${ }^{910}$ but of adrenocorticotrophin, ${ }^{5}$ which has been only recently reported and not yet confirmed as a product of these cells. ${ }^{25}$ It has also been shown not only that there is an increase in and abnormal clustering of neuroendocrine cells in airways close to tumourlets but that these cells express several inappropriate peptides, including adrenocorticotrophin, somatostatin, and vasoactive intestinal polypeptide. ${ }^{424}$

The results of the present study are in keeping with those of previous investigations describing the scarcity of tumourlets, their morphological features, and their tendency to be more often found in the lungs of women. ${ }^{16}$ Although all the lungs bearing them showed some pathological changes, neither scarring, chronic suppuration nor bronchiectasis was a conspicuous feature (table 2). All were immunoreactive for neurone specific enolase and protein gene product 9.5 , which supports their neuroendocrine nature,${ }^{6}$ and all contained gastrin releasing peptide, the peptide most abundant in human pulmonary neuroendocrine cells. ${ }^{10}$ The presence of calcitonin in all but one and absence of leucine-enkephalin from all are in keeping with the results of previous studies also ${ }^{2324}$ but, despite repeated attempts, we could detect 5-hydroxytryptamine in only two of them. Of the six peptide and protein substances we sought that are not considered products of normal human pulmonary neuroendocrine cells (and could therefore be considered inapppropriate), adrenocorticotrophin was present in some cells of two of the tumourlets (fig 3) and growth hormone in all of them (fig 4); none of the others was found.

In association with two of the tumourlets in particular there were greatly increased numbers of neuroendocrine cells, expressing the same pattern of neuroendocrine products as the tumourlets, in an immediately adjacent airway, probably that in which the tumourlet arose (fig $5)$. It has been suggested that, as pulmonary neuroendocrine cells increase in number and change from their well ordered and uniform arrangement within the airways ${ }^{10}$ to become linear arrays or disorganised clusters, ${ }^{422}$ their increasing morphological derangement is accompanied by elaboration of peptides not normally produced by them, such as adrenocorticotrophin, somatostatin, vasoactive intestinal peptide, and apparently growth hormone. ${ }^{45}$ Tumourlets are likely to be the end result of the response of pulmonary neuroendocrine cells to several stimuli, such as hypoxia, inflammation, and other forms of pulmonary injury, rather than a form of minute carcinoid tumour, as has sometimes been claimed. ${ }^{13}$ This process might begin as a simple increase in their number followed by formation of rows of adjacent cells and disorganised clusters. Against this background, a fully fledged tumourlet might develop as an extreme focal proliferative response in occasional circumstances. Although we have examined only a few tumourlets, the differences between their content and that of carcinoid tumours also support this idea. For example, though we could find 5-hydroxytryptamine in only two of the lesions we studied, it appears to be ubiquitous in carcinoid tumours, ${ }^{26}$ whereas the opposite is the case for adrenocorticotrophin, which is rarely found in these neoplasms ${ }^{26}$ but was present in two of our six tumourlets. We have no reason to suppose that our adrenocorticotrophin antiserum was labelling any other peptide; its cross reactivity with both melanocyte stimulating hormone and $\beta$ endorphin was less than $0.1 \%$.

Our finding of growth hormone or a closely related substance cross reacting with it is difficult to interpret. It has been sought very infrequently in endocrine cells or tumours of the lung, though it is certainly described as a product of the latter ${ }^{27}{ }^{28}$; and a possible role in the pathogenesis of certain skeletal and soft tissue abnormalities that may accompany these 
tumours, such as acromegaly, hypertrophic osteoarthropathy, and digital clubbing, has been suggested. ${ }^{29-31}$ Whether it has any trophic effect on the pulmonary tissues around it is unknown. Its prevalence in the pulmonary neuroendocrine cells of diseased lungs and in pulmonary neoplasms, especially those showing neuroendocrine differentiation, needs investigating.

The substances elaborated by tumourlets, and by the increased populations of neuroendocrine cells that probably precede and accompany them, might vary according to several factors, including the nature of the stimulus provoking the change. Whether such "inappropriate" substances as have been described serve any function or are merely aberrations accompanying morphological disorganisation, as seems to be the case with hormone producing tumours, is a matter of conjecture.

We would like to thank Miss Janet Walters, Mrs Heather Kapucu, and Mr Alan Williams for technical and photographic Kapucu, and Mr Alan Williams for technical and photog
assistance and Miss Jill Shaw for typing the manuscript.

1 Whitwell F. Tumourlets of the lung. J Pathol Bacteriol 1955;70:529-41.

2 Bonikos DS, Archibald R, Bensch KG. On the origin of the so-called tumorlets of the lung. Hum Pathol 1976;7:461-9.

3 Ranchod $M$. The histogenesis and development of pulmonary tumorlets. Cancer 1977;39:1135-45.

4 Gould VE, Linnoila L, Memoli VA, Warren WH. Neuroendocrine components of the bronchopulmonary tract: hyperplasias, dysplasias and neoplasms. Lab Invest 1983 49:519-37.

5 Tsutsumi Y, Osamura Y, Watanabe K, Yanaihara N. Immunohistochemical studies on gastrin-releasing peptide and adrenocorticotropic hormone-containing cells in the human lung. Lab Invest 1983;48:623-32.

6 Wharton J, Polak JM, Cole GA, Marangos PJ, Pearse AGE. Neuron-specific enolase as an immunocytochemical marker for the diffuse neuroendocrine system in human fetal lung. J Histochem Cytochem 1981;29:1359-64.

7 Thompson RJ, Doran JF, Jackson P, Dhillon AP, Rode J. PGP 9.5, a new marker for vertebrate neurones and neuroendocrine cells. Brain Res 1983;278:224-8.

8 Sternberger LA. The unlabelled antibody peroxidaseantiperoxidase (PAP) method. In: Sternberger LA, Immunocytochemistry. New York: Wiley, 1979;104-69.

9 Cutz E, Chan W, Track NS. Bombesin, calcitonin and leuenkephalin immunoreactivity in endocrine cells of human lung. Experientia 1981;37:765-7.

10 Gosney JR, Sissons MCJ, Allibone RO. Pulmonary neuroendocrine cell populations in normal human lungs: a quantitative study. Thorax 1988;43:878-82.

11 Becker KL. The Endocrine Lung. In: Becker KL, Gazdar
AF, eds. The endocrine lung in health and disease. Philadelphia: Saunders, 1984:2-46.

12 Pagel W. I. Über den Zusammenhang von ungewöhnlichen Wucherungen atypischen und ortsfremden Epithels der Bronchien mit Bronchiektasien. II. Untersuchungen über adenomartige Verästelungen der Bronchien des Meerschweinchens. Virchs Arch Pathol Anat 1926;262. 583-94.

13 Churg A, Warnock ML. Pulmonary tumourlet. A form of peripheral carcinoid. Cancer 1976;37:1469-77.

14 Stewart MJ, Allison PR. A microscopic focus of oat cell carcinoma in a bronchiectatic lung. J Pathol 1943;55: 105-7.

15 Spain DM, Parsonnet V. Multiple origin of minute bronchiolargenic carcinomas. Report of a case. Cancer bronchiolargenic

16 Prior JT, Jones DB. Minute peripheral pulmonary tumours. A study of eight cases. $J$ Thorac Surg 1952;23:224-36.

17 Spencer H, Raeburn C. Atypical proliferation of bronchiolar epithelium. J Pathol Bacteriol 1954;67:187-93.

18 Kay S. Histologic and histogenic observations on the peripheral adenoma of the lung. Arch Pathol 1958;65: 395-402.

19 Mikail M, Sender B. Nodular epithelial hyperplasia (tumorlets) of the lungs. Report of a case. Am J Clin Pathol 1962;37:515-20.

20 Hausman DJ, Weimann RB. Pulmonary tumorlet with hilar lymph node metastasis. Report of a case. Cancer 1967; 20:1515-9.

21 MacMahon HE, Werch J, Sorger K. Tumorlet of bronchus with a 12 year follow-up. Arch Pathol 1967;83: 359-63.

22 Gosney JR, Sissons MCJ, Allibone RO, Blakey AF. Pulmonary endocrine cells in chronic bronchitis and emphysema. J Pathol 1989;157:127-33.

23 Cutz E, Chan W, Kay JM, Chamberlain DW. Immunoperoxidase staining for serotonin, bombesin, calcitonin and leu-enkephalin in pulmonary tumorlets, bronchial carcinoids and oat cell carcinomas [abstract]. Lab Invest 1982;46:16A.

24 Watanabe $H$, Kobayashi $H$, Honma $K$, Ohnishi $Y$, Iwafuchi M. Diffuse panbronchiolitis with multiple tumourlets. A quantitative study of the Kultschitzky cells and their clusters. Acta Pathol Jpn 1985;35:1221-3.

25 Watanabe H. Pathological studies of neuroendocrine cells in human embryonic and fetal lung. Light microscopical, immunohistochemical and electron microscopical approaches. Acta Pathol Jpn 1988;38:59-74.

26 Gould VE, Warren WH, Memoli VA. Neuroendocrine neoplasms of the lung. In: Becker KL, Gazdar AF, eds. The endocrine lung in health and disease. Philadelphia: Saunders, 1984:406-45.

27 Cameron DP, Burger HG, De Kretzer DM, Catt KJ, Best JB. On the presence of immunoreactive growth hormone in a bronchogenic carcinoma. Aust Ann Med 1969;18: $143-6$.

28 Greenberg PB, Beck C, Martin TJ, Burger HG. Synthesis and release of human growth hormone from lung carcinoma in cell culture. Lancet $1972 ; \mathrm{i}: 350-2$.

29 Dabek JT. Bronchial carcinoid tumour with acromegaly in two patients. J Clin Endocrinol Metab 1974;38:329-33.

30 Steiner H, Dahlbäck O, Waldenström J. Ectopic growth hormone production and osteoarthropathy in carcinoma of the bronchus. Lancet 1968;i:783-5.

31 Gosney MA, Gosney JR, Lye M. Plasma growth hormone and digital clubbing in carcinoma of the bronchus. Thorax 1990;45:545-7. 